\title{
RETURN MIGRATION DURING CORONAVIRUS DISEASE (COVID-19) OUTBREAK IN SPECIAL REGION OF YOGYAKARTA, INDONESIA
}

\author{
Agus Joko Pitoyo ${ }^{1}$, Bagas Aditya ${ }^{2}$, Sumini $^{3}$, Arga Nugraha $^{4}$, Septi Nurhayati ${ }^{5}$ \\ 1,2 Department of Environmental Geography, Faculty of Geography, Universitas Gadjah Mada \\ ${ }^{1,3}$ Center for Population and Policy Studies, Universitas Gadjah Mada \\ ${ }^{4,5}$ Board of National Population and Family Planning, Jakarta \\ Email: aguspit@ugm.ac.id
}

\begin{abstract}
Population mobility during pandemic becomes the concern for government since COVID-19 has known spreading through droplets. Special Region of Yogyakarta is one of the provinces in Indonesia that is dealing with the problem of population mobility, especially in return migration during the pandemic. This study aims to give short analysis on the potency of return migration. This study is essential both for academic and practitioner in managing population mobility during pandemic. The analysis was supported by statistical data from Ministry of Health of the Republic of Indonesia, news, and related journals. This study confirms that return migration during the pandemic plays a role in causing new transmission centers. It means that migrants have a role in carrying the virus, in which the severity of its spread is determined by the interactions between infected migrants and local community and between infected local community and other local community. Lockdown in the local level such as villages is considerably more effective rather than massive travel bans in regional level. Local lockdown is considered to be more effective because it makes easy in controlling and also give little impact to the economic condition. Social capital and grassroot involvement is key to stop this pandemic.
\end{abstract}

Keywords: Migration; COVID-19; Public Health

\section{A. INTRODUCTION}

At the end of 2019, the world was faced with the problem of Coronavirus Disease (COVID-19) outbreak which rapidly spread in Wuhan, China. This disease, which obviously attacks the respiratory tract, is caused by a virus called Severe Acute Respiratory Syndrome Coronavirus 2 (SARS-Cov-2). This virus can originate in bats after transmitting intermediate hosts (MacKenzie \& Smith, 2020; Salata et al., 2020). Since it first infected people in Wuhan, the virus has spread rapidly to various countries and it has pushed the World Health Organization (WHO) to declare this outbreak as a pandemic (WHO, 2020b). At the end of April 2020, there were 3 million people from 210 countries that were infected with the COVID-19, far more spread out than SARS and MERS, each infecting only 26 and 27 countries (Peeri et al., 2020; WHO, 2020a).

The widely spread of COVID-19 occurs due to the transmission between humans to humans (Rothan \& Byrareddy, 2020). The era of globalization with the 
high population mobility rate has accelerated the spread of a virus (Saker et al., 2004). Historically population mobility or migration has long been considered as a contributing factor in the spread of infectious diseases (Kraemer et al., 2019; Saker et al., 2004). (Soto, 2009) stated that migration creates opportunity to the spread of infectious disease. Migration has long been known as a source of epidemics and partly influences the outcome of a conflict or social change (Wilson, 2005). (Saker, Lance; Lee, Kelley; Cannito, Barbara; Gilmore, Anna, Campbhell-Lendrum, 2018) argues that migration brings a person into contact with new microbes and vectors, new gene assemblages, immunological structures, cultural preferences, behavioral patterns, and technology, which influence the risk of transmission. In the case of SARS in 2004, (Ali \& Roger, 2008) stated that the movement of people between global city gave big role in the spread of this virus in Beijing, Hong Kong, Toronto, Singapore, and Taiwan; this case also happened on the spread of HIV in the center of city which have high population mobility (Gould, 1999).

Potential outbreaks of pandemics caused by migration have led many countries to limit population mobility. China was the first country that applied a total restriction on all population mobility activities through its regional quarantine policy, which was then followed by other countries, such as Italy, France, some areas in Singapore, and Spain. The purpose of limiting population mobility is to reduce transmission of COVID-19 so that the number of patients does not exceed the capacity of the hospital. However, many countries do not fully implement regional quarantine policies, such as Indonesia, South Korea, and some states in the United States.

Indonesia is one country that was also infected by COVID-19 as of May 3, 2020, and 11,192 people were infected (covid19.go.id, 2020). Despite having a high risk of transmission due to the large population and high population density in urban areas, Indonesia does not implement a policy of total population mobility restrictions. The policy adopted by Indonesia is limited population mobility through the Large-Scale Social Restrictions (PSBB) policy issued in (Peraturan Pemerintah Republik Indonesia Nomor 21 Tahun 2020 Tentang Pembatasan Sosial Berskala Besar Dalam Rangka Percepatan Penanganan Corona Virus Disease 2019 (COVID-19), 2020), which means that population mobility can still occur with certain objectives. This condition is considered to be able to increase the potential surge in COVID-19 cases in Indonesia, especially as Indonesia faces the moment of Eid al-Fitr, in which in the common years, there will usually be a wave of return migration. 


\section{B. MATERIALS AND METHODS}

This study used the data of COVID19 in the Special Region of Yogyakarta that periodically published via website (Corona.jogjaprov.go.id, 2020). The data included demographic data of patients with positive coronavirus, transmission models, and travel history carried out by these patients. In addition to using data on the number of patients with positive COVID19 , this study also used daily migration data during the pandemic obtained from the Yogyakarta Transportation Agency. The COVID-19 cases and migration data during this pandemic were then processed using descriptive statistics with graphs, tables, and crosstabs. Descriptive statistics such as percentage, mean, median, and modus is useful to figure out the general data and explore new information without any purpose to find statistics correlation. Table, graphs, and crosstab was chosen to represent data and help analysis easily. Moreover, the analysis method used in this study is descriptive analysis, according to (Gabor, 2010) descriptive analysis has advantage in giving multidimensional

\section{RESULTS AND DISCUSSION}

\section{Profile of COVID-19 Cases in DIY}

The number of COVID-19 cases in DIY is not same among regencies, in which there are regencies with a high number of COVID-19 cases while others are low analysis that are strong and effective in explaining new phenomenon/facts.

\section{Description of Area}

Special Region of Yogyakarta (DIY) is one of the provinces in Indonesia which has a high potential for the explosion of COVID-19 cases since it is located in Java, close to provinces with the epicenter of COVID-19 in Indonesia, including Jakarta, West Java, and East Java. On the other hand, inter-regional population mobility in Java also occurred very intensively during the outbreak. Based on data from the Task Force for the Acceleration of COVID-19 Mitigation in DIY, on March 25-30, 2020, there were 70,875 migrants entering the DIY region (Pertana, 2020a). Even after a ban on migration by the government, there was still an increase of 7,000 people (Priatmojo, 2020b). This condition can certainly increase the risk of an explosion of COVID-19 cases in DIY if migrants can really play a role in spreading the plague. Therefore, to answer this question, this study aims to determine whether return migration during the COVID-19 pandemic can play a role in the spread of the virus and how the process explains it.

(Figure 1). There were 115 positive cases, two from the regions other than DIY on May 3, 2020. The number of positive cases by regency was Sleman Regency (51 cases), followed by Bantul Regency (31 cases), Gunungkidul Regency (14 cases), 
Yogyakarta City (12 cases), and Kulon Progo (5 cases). The number of cases in Kulon Progo Regency was the lowest one compared to other regions, as well as the City of Yogyakarta. This is an anomaly of the characteristics of cases of the epicenter of COVID-19 that occurred in Indonesia, which usually occur in the center of city. Meanwhile, the epicenter of DIY was in the suburbs. Sleman Regency is administratively not a city area, but the

\section{administratively not a city area, but the}

function of this regency is to support the function of the City of Yogyakarta. Activities, such as education, health, and economic centers are run in this area. This causes the dynamics of population mobility, both from within and outside the region in Sleman Regency, more dynamic. Therefore, it is common that Sleman Regency has a relatively higher risk in the COVID-19 cases in DIY than other regencies.

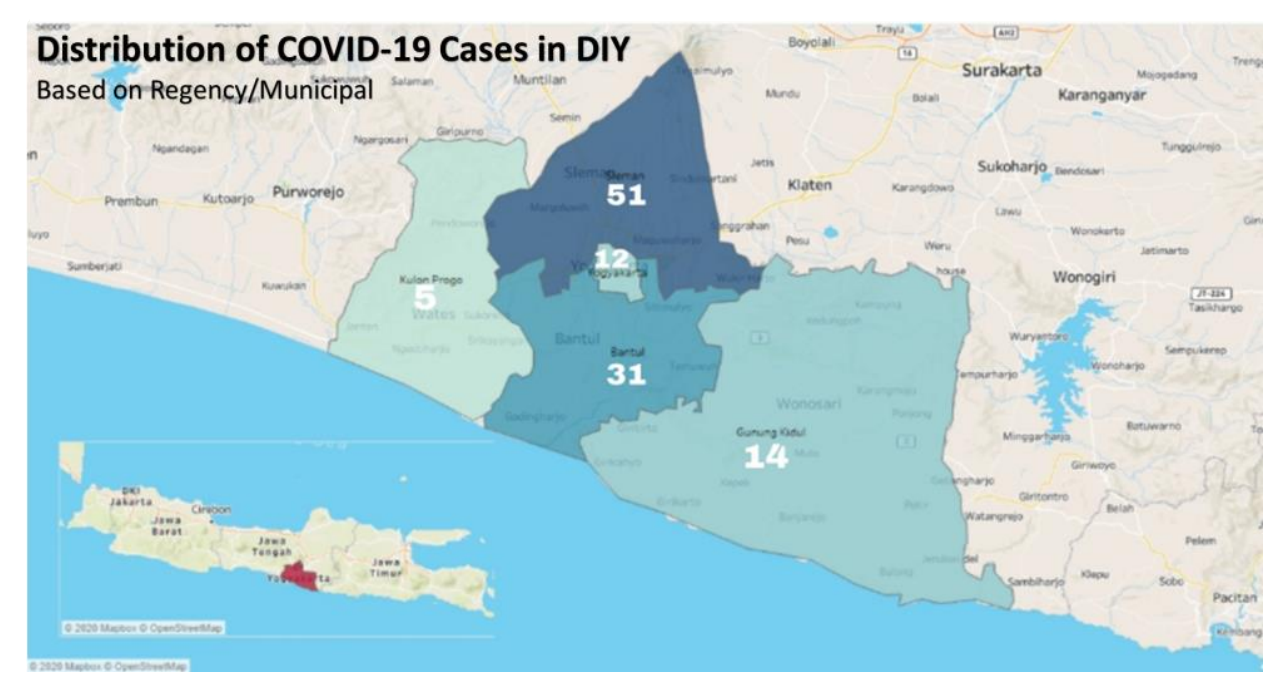

Figure 1. Map of Number of Cases by Regency/City in DIY Source: (Corona.jogjaprov.go.id, 2020)

Based on the demographic characteristics, the highest positive case is people aged 46-55 years (25.66\%) (Figure 2). This age classification was made based on the Ministry of Health of the Republic of Indonesia's guidelines (2009) on the official website (depkes.go.id), in which the age of 46-55 years is classified as the early elderly. Based on the publication of the Ministry of Health of the Republic of Indonesia, the highest distribution of the elderly population in Indonesia is in the Special Region of Yogyakarta, which is 13.4 percent in 2015 (Kemenkes, 2016). Yogyakarta with its high number of elderly people has caused this area face high risk if there is an increase in incoming migration (many incoming travelers). 


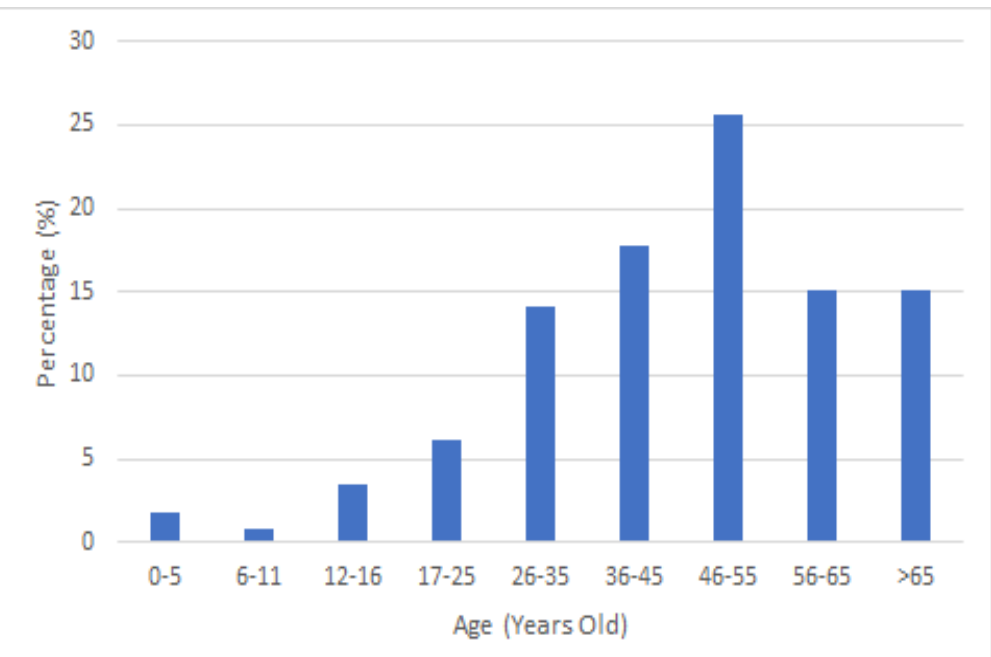

Figure 2. Distribution of Number of COVID-19 Cases by Population Demographic Characteristics Source: (Corona.jogjaprov.go.id, 2020)

The majority of positive cases are caused by factors outside the region or a travel history (Figure 3). In the middle of March to April, many cases were originated from Jakarta, Bogor, and West Java. Also, the people with some cases had a travel history, such as Singapore and London, in which after receiving the treatment, both of the patients of these cases had been recovered. On April 25, 2020, a total of four Indian citizens in the Sleman Regency were tested positive COVID-19. Three days later, it was followed by five positive cases originating from the tracing results of positive Indian citizen. The spread was going on due to religious activities followed by the Indian citizens that were still active in the mosque located in the Depok Subdistrict, Sleman Regency. A group of cases originating from religious activities was also experienced by people who returned from Islamic mass gathering (tabligh akbar) activities in Jakarta. The transmission after these several pilgrims had arrived in Yogyakarta remained to increase based on contact history tracing. The distribution among these pilgrims was discovered after one pilgrim died in Yogyakarta on April 5, 2020. Then, it was followed by positive cases from April 18 to May 2 with the same case contact. In May, along with the month of Ramadan, the positive cases increased due to the high number of homecoming people. Some came from Islamic boarding schools in East Java, migrant workers from Dubai, the United States, and Islamic mass gathering from Gowa. 


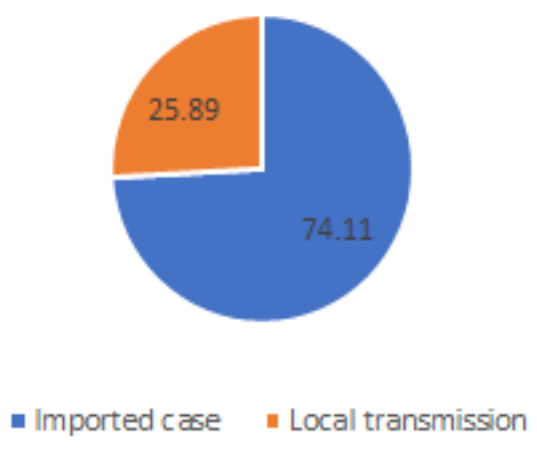

Figure 3. Proportion of COVID-19 Cases by Transmission (Data of COVID-19 on May 3, 2020) Source: (Corona.jogjaprov.go.id, 2020)

Migration during Emergency of March 2020, there were at least 100 COVID-19 in DIY

Population migration during the countries that applied either full or partial lockdown after the COVID-19 cases were COVID-19 pandemic is a major concern found in their countries (Figure 4). for governments in several countries since (Dunford et al., 2020) state that this it has discovered that the spread of the lockdown is a state effort to manage the coronavirus is very fast and person-tospread of the virus so that it does not have person transmission. By the middle of a greater impact.

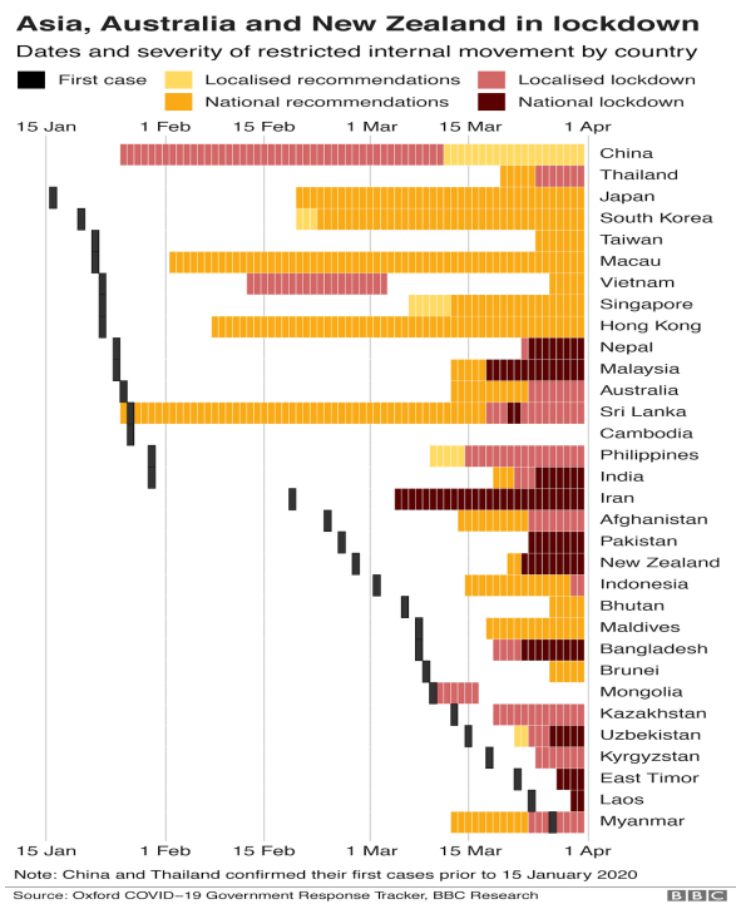

Figure 4. List of Countries in Asia, Australia, and New Zealand that Implement Lockdown Source: (Dunford et al., 2020) 
Trend of Migration before National

\section{Restriction}

The fact that population mobility can potentially spread COVID-19 in several countries in the world do not immediately make Indonesia apply quarantine since the beginning of this case (Figure 4). The main reason for not implementing the regional quarantine is because of fears of economic failure, especially for informal workers. This makes the population mobility in Indonesia remain intensively occuring since this case began on March 2, 2020. The Indonesian central government does not implement regional quarantine, whereas as an archipelago state, regional quarantine is a good option to suppress the expansion of the spread of COVID-19. An inter-island mobility restriction is basically much easier than an inter-regional population mobility restriction because the choice of inter-island transportation modes is ships or planes only and the routes are very easily controlled by the government. If this "island quarantine" can be applied from the beginning, the government will focus on controlling the spread of the virus only in the area of Java.

Control over mobility in the regions of Java is indeed a difficult thing to do because the transportation network on the island of Java is the most complete transportation network compared to other islands in Indonesia. The flow of migration between regions is also high because the economic interaction between provinces on Java is very high. Besides, at the time of this outbreak, the Indonesian people also encounter a "homecoming" moment, which is the return migration activity of urban communities is carried out every annual national holiday.

DIY is one of the provinces in Java that faces problems related to return migration during the pandemic. More than 84 thousand DIY people doing outgoing migration in 2015 (BPS, 2017). Many migrated to cities to escape from poverty (Pitoyo \& Alfana, 2015). The high level of outgoing migration has the potential to cause return migration. The return migration done together by all migrants generally occurs at certain moments. However, in times of urgency, it may be that migration will not wait for that moment, as happens during this pandemic.

The number of return migrants entering DIY since the beginning of the case has reached more than 80,000 people, most of whom are migrants returning from the Jabodetabek area. There are several explanations regarding the causes of the flow of return migration during the pandemic:

1. Cessation of Community Economic Activities during the Pandemic

The pandemic epicenter in Indonesia is located in the metropolitan area which has been a destination for migrant workers from various regions, one of them is Indonesia. Most migrant workers in the metropolitan 
area occupy informal urban sectors, such as trade and services. The outbreak followed by an appeal for physical distancing caused the community not to do many activities outside their home, thus some economic sectors, such as trade and transportation services, lost their customers. (Nurhadi, 2020) states that the flow of return migration from migrant workers does not only occur in internal migrant workers but also international migrant workers. Until April 22, BNP3TKI recorded that the number of international migrant workers returning to DIY had reached 130 people. The wave of return migration as a result of the economic collapse in urban areas is usually carried out by economically lower-class people who rely on economic activity in the informal sector.

\section{Moment of Annual Return Migration} (Homecoming)

Homecoming is a culture that is commonly practiced by the Indonesian people ahead of major holidays, such as Christmas, Eid al-Fitr, and New Year. The main purpose of this return migration is to gather with extended families in the area. Homecoming is usually experienced by migrant communities in urban areas at certain spiritual and cultural moments (Siahaan, 2019). Homecoming is a big problem during outbreaks, especially when the epicenter of the epidemics in Indonesia is in urban areas, whereas in general, urban areas in Indonesia are built by migrant communities (Somantri, 2000). Moreover, homecoming becomes a big threat to the spread of the virus because it does not have a mechanism for selecting the socioeconomic status of migrant communities, in which it is usually done by all groups of people, either low or high economic society.

The number of return migration in DIY increases due to the backflow of migrant workers residing in Jakarta. Gunungkidul Regency is one with the highest number of return migrants in DIY because most people in Gunungkidul are looking for work in urban areas by becoming traders. The flow of return migration to DIY then causes an increase in the number of people under monitoring (Orang Dalam Pengawasan-ODP) in DIY because Sri Sultan HB X (Governor of DIY) declared that all return migrants are classified as ODP (Jiwandono, 2020) to facilitate monitoring of the possible spread of the virus in DIY. Based on data published in (Corona.jogjaprov.go.id, 2020), there were 46 ODP on March 19, 2020 and 3.070 ODP on April 9, 2020.

\section{Trend of Migration after National}

\section{Restriction}

The ban on return migration in Indonesia was started by the central government on April 21, 2020. The ban against return migration was issued in (Peraturan Menteri Perhubungan Republik Indonesia Nomor PM 25 Tahun 2020 Tentang Pengendalian Transportasi Selama 
Masa Mudik Idul Fitri Tahun 1441 Hijriah

Dalam Rangka Pencegahan Penyebaran Corona Virus Disease 2019 (COVID-19), 2020) concerning Transportation Control during the Eid al-Fitr Homecoming of 1441 Hijri in the Context of Preventing the Spread of COVID-19. This regulation was applied in April 24, 2020. The issuance of this regulation is expected to be able to suppress or even eliminate the rate of return migration during the outbreak in Indonesia. However, this ban is limited to cases of migration originating from epicenter areas. Besides being limited to certain regions, this ban was also excluded for inter-regional logistics traffic.

Information on this regulation caused a high increase in the number of migrants who chose to migrate before the regulation was implemented. (Wijana, 2020) states that two days before the regulation was implemented, there was an increase in the influx of migration to DIY, especially in Gunungkidul Regency. Wahyu Nugroho, the head of the Gunungkidul Department of Transportation, said that the number of migrants entering Gunungkidul before the stipulation of the regulation had reached 5.350 return migrants in March 31, 2020, 9.831 migrants in April 21, 2020 and 10.119 migrants in April 22, 2020 (Daruwaskita, 2020; Priatmojo, 2020a).

In the implementation of the regulation on the ban of return migration, there are still violations, one of them is the emergence of the phenomenon of people who want to migrate using the services of smugglers. The smugglers are offered to provide transportation for travelers by smuggling them into transportation, such as trucks and pickups. Most of the smugglers are logistic transportation owners who take advantage of the looseness of government regulations that allow logistical transport traffic among regions. This shows that the issuance of regulations banning migration can lead to a wave of illegal migration which is certainly more likely to increase the risk of migrants exposed to the virus during the trip.

Efforts to deal with the influx of return migration to DIY during the outbreak were not only carried out by local governments, but also by the community at the village level. The community strictly screened people entering their village area. This lasted for some time until finally the community's policy changed since the middle of April. The number of other countries implementing regional lockdown has inspired some villagers to adopt it at the village level. This policy was carried out sporadically without the command of the local government. By the closure of several villages, this also caused a wave of rejection of migrants in DIY. However, it did not result in the number of migrants entering DIY to decrease to none at all because Tavip Agus Rayanto, the chief of Department of Transportation Daerah Istimewa 
Yogyakarta, there were 85.876 return migrants entering DIY from April 1 to May 2, 1.433 migrants came from red zone of COVID-19 (Husna, 2020). Sleman and Gunung Kidul are the regencies with the highest return migrants. The Head of Public Relation and Protocol Sleman Regional Government, Shavitri Nurmala Dewi, said that there were 6.985 return migrants until April 27, 2020 (Setiawan, 2020). The Head of Communication and Information Department Gunung Kidul Regency, Kelik Yuniantoro, said that there were 10.381 return migrants entering Gunung Kidul in April 26, 2020; 2.631 migrants from DKI Jakarta, 1.842 migrants from West Java, and three international migrants (Gabrillin, 2020). Return migrants did not only come from other regions in Indonesia, but they also came from other countries or called migrant workers. BP3TKI DIY head stated that from March to April, there were more than 130 return migrant workers entering DIY (Nurhadi, 2020).

\section{How Migration Can Accelerate COVID- 19 in DIY?}

The positive cases of COVID-19 in DIY was first discovered on March 16, 2020. In this first case, the patient had a travel history from the epicenter area of the epidemic, West Java. Several subsequent cases also had the same case of the patient having a travel history from the affected area. This proves that migration can play a role in bringing disease outbreaks to the regions. On the other hand, it did not rule out the possibility that the virus actually had spread in DIY but it was only detected when migrants who were ODP received special attention, so they got a chance to check whether or not they were positive for COVID-19. Besides, migrants originating from the epicenter area tended to be more alert to any symptoms they experienced so that the awareness to conduct a positive COVID-19 test might be higher than that of the local community. As being noted that the symptoms of COVID-19 are almost the same as that of influenza, it does not rule out the possibility that the local community has been infected but do not do the test because they feel they are not at risk.

Based on the results of the analysis of the COVID-19 Task Force Team in DIY, the spread of the COVID-19 virus in this province is divided into three generations, including cases that are infected in the first generation (G1), G2 is a case that is contracted from the G1 generation, and G3 is a case that contracting from G2. Transmission in the first generation is caused by transmission from positive migrants of COVID-19. The people who are infected by the migrants then form new clusters of transmission into the second and third generations.

The percentage of negative COVID19 migrants is certainly greater than positive COVID-19 migrants. However, even a small proportion of infected migrants will still be 
at risk of causing explosion cases in DIY.

This is because migrants who have the potential as carriers of the virus will interact with the local community. There are two possible forms of interaction between migrant communities and local communities that can play a role in spreading the COVID19 virus.

\section{Family Reunion}

One form of return migration during the outbreak in DIY is "homecoming", that is a migratory event that is usually carried out by every family member who wanders in other areas. Tari, a migrant in Jakarta, states that the desire to return migration is to gather with family and care for their children during the outbreak (Siahaan, 2019). The migrants who successfully enter their home regions interact with their families and are more intensive because alienation of family members may be taboo to do. Therefore, the potential for spreading the virus becomes high because migrants immediately gather with families. Then, if one family is infected, this will potentially re-transmit the virus to the surrounding community.
2. Interaction between Migrants and Local Community

The DIY community is a society that is very tolerant of the presence of migrants in the midst of their interaction environment. Based on studies from the Center for Population and Policy Studies in 2019, it showed that $90 \%$ of the people of DIY accepted migrants who entered their communities, especially return migrants with various requirements (Table 1). This attitude of openness towards migrants becomes a gap for the spread of the virus from migrants to local communities. However, this type of model might occur in the flow of migration that occurs at the beginning, in which the issue of migration that carries the disease has not been a major concern for the community. The attitude of acceptance towards migrants can then change with the amount of information and comparison with other regions that have experienced cases of virus transmission from the migrant community to the local community.

Table 1. Local community acceptance of return migrants during the pandemic

\begin{tabular}{cc}
\hline Responses to Return Migrants & Percentage \\
\hline Are refused & 9.51 \\
\hline Are allowed with permission issued by local government (RT) & 38.96 \\
\hline Are allowed with health certificate issued by health center or hospital & 46.77 \\
\hline Are allowed without any requirements & 4.76
\end{tabular}

Source: Primary Data from Center for Population and Policy Studies (CPPS) UGM, 2020 
D. CONCLUSIONS

This study confirms that return migration during the pandemic plays a role in causing new transmission centers. It means that migrants have a role in carrying the virus, in which the severity of its spread is determined by the interactions between infected migrants and local community and between infected local community and other local community. The COVID-19 positive cases in DIY first occurred in migrants who had a travel history in an area where the outbreak occurred. Subsequent cases occurred through local transmission and transmission outside the region. This proves that migrants are able to bring disease to an area. There are two models that can cause the spread of viruses carried by migrant communities, including family reunions and intensive interactions between local communities and migrants. Return migrants, who are part of the local community migrating outside the region, are one big challenge because the community's acceptance towards the migrants is higher since the migrants are considered part of the family. However, a vigilance against the spread of the virus has ultimately encouraged collective efforts as a community at the village level to reject migrants.

Migration during the pandemic becomes a major challenge for the Indonesian government, especially the DIY government. A ban on return migration in regional level will not be effective in suppressing imported cases because government could not control effectively so that several waves of migration are still possible. On the other hand, even though the number of migrations exposed is small, this condition can cause an outbreak in DIY if local transmission occurs between communities like what is stated on news article by (Pertana, 2020b) that there is already local transmission in DIY. The mobility ban may be more effective applied in local area such as villages. Local lockdown may make easy in controlling and may give little impact to the economic sector rather than regional lockdown. The researchers also strongly recommend government to limiting interactions and doing contact tracing to inhibit the outbreak of COVID-19 in the community just like (Bi et al., 2020) concluded in their study.

In the case of applying effective regulations during the outbreak, it recommends that the government should issue the preventive regulations rather than the repressive one to maintain the security and stability of the community during the pandemic. Besides, rooted regulations are required to be implemented, meaning that government regulations need to include the collective awareness of the community at the lower levels. This collegial collective awareness can be more effective to be applied by the community, mainly in terms of responding to the arrival of migrants in 
the village. This collective response is an important social capital for the government in suppressing the spread of epidemics due to return migration, which is difficult to control if this is only implemented by providing top-down policies.

\section{E. REFERENCES}

Ali, S. H., \& Roger, K. (2008). Networked Disease: Emerging Infections in the Global City. Wiley-Blackwell Publishing.

Bi, Q., Wu, Y., Mei, S., Ye, C., Zou, X., Zhang, Z., Liu, X., Wei, L., Truelove, S. A., Zhang, T., Gao, W., Cheng, C., Tang, X., Wu, X., Wu, Y., Sun, B., Huang, S., Sun, Y., Zhang, J., ... Feng, T. (2020). Epidemiology and transmission of COVID-19 in 391 cases and 1286 of their close contacts in Shenzhen, China: a retrospective cohort study. The Lancet Infectious Diseases, 20(8), 911-919. https://doi.org/10.1016/S14733099(20)30287-5

BPS. (2017). Recent Migration. In Report.

Corona.jogjaprov.go.id. (2020). Yogyakarta Tanggap COVID-19. Https://Corona.Jogjaprov.Go.Id/.

covid19.go.id. (2020). Berita resmi COVID19 - Protokol terbaru COVID-19. Https://Covid19.Go.Id/. https://covid19.go.id/

Daruwaskita. (2020, March 31). Lima Hari, 5000 Lebih Pemudik Pulang Kampung ke Gunungkidul. IDN Times Jogja. https://jogja.idntimes.com/news/jogj a/daruwaskita/lima-hari-5000-lebihpemudik-pulang-kampung-kegunungkidul/1

Dunford, D., Dale, B., Stylianou, N., Lowther, E., Ahmed, M., \& Arenas, I. de la T. (2020). Coronavirus: The world in lockdown in maps and charts.

BBC

News.

https://www.bbc.com/news/world52103747

Gabor, M. R. (2010). Descriptive methods of data analysis for marketing data â $\epsilon^{\prime \prime}$ theoretical and practical considerations. Management Şi Marketing (Bucureşti), 5(3).

Gabrillin, A. (2020, April 26). Pemudik dari Zona Merah Masih Berdatangan ke Gunungkidul. Kompas.Com. https://regional.kompas.com/read/20 20/04/26/15513101/pemudik-darizona-merah-masih-berdatangan-kegunungkidul?page $=$ all

Gould, P. (1999). Becoming a Geographer. Syracus University Press.

Husna, M. A. (2020, May 4). Sedikitnya 85.876 Pemudik Masuk Wilayah DIY, Lebih dari 80 Persen dari Jabodetabek. TribunNews.Com. https://www.tribunnews.com/region al/2020/05/04/sedikitnya-85876pemudik-masuk-wilayah-diy-lebihdari-80-persen-dari-jabodetabek

Jiwandono, R. (2020, March 26). Semua Pendatang di Yogyakarta Berstatus ODP. Tagar.Id. https://www.tagar.id/semuapendatang-di-yogyakarta-berstatusodp-corona

Kemenkes. (2016). Situasi Lanjut Usia (lansia) di Indonesia. Kementerian Kesehatan Republik Indonesia. https://pusdatin.kemkes.go.id/article/ view/16092300002/infodatin-situasilanjut-usia-lansia-di-indonesia.html

Kraemer, M. U. G., Golding, N., Bisanzio, D., Bhatt, S., Pigott, D. M., Ray, S. E., Brady, O. J., Brownstein, J. S., Faria, N. R., Cummings, D. A. T., Pybus, O. G., Smith, D. L., Tatem, A. J., Hay, S. I., \& Reiner, R. C. (2019). Utilizing general human movement models to predict the spread of emerging infectious diseases in resource poor settings. Scientific Reports, 9(1), 1-11. https://doi.org/10.1038/s41598-019- 
41192-3

MacKenzie, J. S., \& Smith, D. W. (2020). COVID-19: A novel zoonotic disease caused by a coronavirus from China: What we know and what we don't. Microbiology Australia, 41(1), 4550. https://doi.org/10.1071/MA20013

Peraturan Menteri Perhubungan Republik Indonesia Nomor PM 25 Tahun 2020 Tentang Pengendalian Transportasi Selama Masa Mudik Idul Fitri Tahun 1441 Hijriah Dalam Rangka Pencegahan Penyebaran Corona Virus Disease 2019 (COVID-19), Menteri Perhubungan Republik Indonesia (2020). http://dx.doi.org/10.1016/j.cirp.2016 $.06 .001 \% 0$ Ahttp://dx.doi.org/10.101 6/j.powtec.2016.12.055\%0Ahttps://d oi.org/10.1016/j.ijfatigue.2019.02.00 6\%0Ahttps://doi.org/10.1016/j.matle t.2019.04.024\%0Ahttps://doi.org/10. 1016/j.matlet.2019.127252\%0Ahttp: //dx.doi.org/10.1016

Nurhadi, M. (2020, April 22). Efek Covid19, Ratusan Pekerja Migran Kembali ke DIY. SuaraJogja.Id. https://jogja.suara.com/read/2020/04 /22/080000/efek-covid-19-ratusanpekerja-migran-pulang-kediy?page $=$ all

Peeri, N. C., Shrestha, N., Rahman, M. S., Zaki, R., Tan, Z., Bibi, S., Baghbanzadeh, $\quad$ M., Aghamohammadi, N., Zhang, W., \& Haque, U. (2020). The SARS, MERS and novel coronavirus (COVID-19) epidemics, the newest and biggest global health threats: what lessons have we learned? International Journal of Epidemiology, 49(3), 717726.

https://doi.org/10.1093/ije/dyaa033

Pertana, P. R. (2020a, April 1). Terus Bertambah, Pemudik Tiba di Yogya Tembus 100 Ribu Orang. Detik News. https://news.detik.com/beritajawa-tengah/d-4961757/terus- bertambah-pemudik-tiba-di-yogyatembus-100-ribu-orang

Pertana, P. R. (2020b, April 22). Gugus Tugas COVID-19: Sudah Ada Transmisi Lokal Corona di DIY. Detik News. https://news.detik.com/berita-jawatengah/d-4987486/gugus-tugascovid-19-sudah-ada-transmisi-lokalcorona-di-diy

Pitoyo, A. J., \& Alfana, M. A. F. (2015). Strategi Rumah Tangga Miskin Perdesaan Keluar Dari Kemiskinan: Kasus Tiga Desa Di Kulon Progo, Daerah Istimewa Yogyakarta. Populasi, 23(2), 55-70. https://doi.org/10.22146/jp.15695

Priatmojo, G. (2020a, April 23). Sejak Jokowi Umumkan Larangan Mudik, Pemudik ke Gunungkidul Malah Meningkat. SuaraJogja.Id. https://jogja.suara.com/read/2020/04 /23/071000/sejak-jokowi-umumkanlarangan-mudik-pemudik-kegunungkidul-malah-meningkat

Priatmojo, G. (2020b, April 26). Hingga Hari Kedua Larangan Mudik, Hampir 7000 Pemudik Masuk ke Sleman. SuaraJogja.Id. https://jogja.suara.com/read/2020/04 /26/065000/hingga-hari-kedualarangan-mudik-hampir-7000pemudik-masuk-ke-sleman

Peraturan Pemerintah Republik Indonesia Nomor 21 Tahun 2020 Tentang Pembatasan Sosial Berskala Besar Dalam Rangka Percepatan Penanganan Corona Virus Disease 2019 (COVID-19), Sekretariat Negara 8 (2020). https://doi.org/10.4324/9780367802 820

Rothan, H. A., \& Byrareddy, S. N. (2020). The epidemiology and pathogenesis of coronavirus disease (COVID-19) outbreak. Journal of Autoimmunity, 109(February), 102433. https://doi.org/10.1016/j.jaut.2020.1 02433 
Saker, Lance; Lee, Kelley; Cannito, Barbara; Gilmore, Anna, CampbhellLendrum, D. (2018). Globalization and infectious diseases. Biodiversity and Evolution, 3, 123-137. https://doi.org/10.1016/B978-178548-277-9.50008-5

Saker, L., Lee, K., Cannito, B., Gilmore, A., \& Campbell-Lendrum, D. (2004). Globalization and Infectious Diseases: A review of linkages (WHO). Social, Economic and Behavioural (SEB) Research, 3, 55. https://www.who.int/tdr/publications /documents/seb_topic3.pdf

Salata, C., Calistri, A., Parolin, C., \& Palù, G. (2020). Coronaviruses: A paradigm of new emerging zoonotic diseases. Pathogens and Disease, 77(9), 1-5. https://doi.org/10.1093/femspd/ftaa0 06

Setiawan, J. H. W. (2020, April 28). Pemudik yang Sudah Masuk ke Sleman Capai 6.985 Orang. Detik News. https://news.detik.com/beritajawa-tengah/d-4993679/pemudikyang-sudah-masuk-ke-sleman-capai6985-orang

Siahaan, H. (2019). Memahami Fenomena Tradisi Mudik Menurut Dosen Sosiologi UNAIR. Universitas Airlangga.

https://www.unair.ac.id/site/article/r ead/2525/memahami-fenomenatradisi-mudik-menurut-dosensosiologi-unair.html

Somantri, G. R. (2000). Village in Motion.
Time Publisher.

Soto, S. M. (2009). Human migration and infectious diseases. Clinical Microbiology and Infection, 15(SUPPL. 1), 26-28. https://doi.org/10.1111/j.14690691.2008.02694.x

WHO. (2020a). Coronavirus disease (COVID-19) Weekly

Epidemiological Update and Weekly Operational Update. World Health Organization.

https://www.who.int/emergencies/di seases/novel-coronavirus-

2019/situation-reports

WHO. (2020b). WHO Director-General's opening remarks at the media briefing on COVID-19 - 11 March 2020. World Health Organization. https://www.who.int/directorgeneral/speeches/detail/whodirector-general-s-opening-remarksat-the-media-briefing-on-covid-19--11-march-2020

Wijana, E. P. E. (2020, April 25). Mudik Dilarang, Gunungkidul Alami Lonjakan Jumlah Perantau Pulang Kampung. SuaraJogja.Id. https://jogja.suara.com/read/2020/04 /25/190209/mudik-dilaranggunungkidul-alami-lonjakan-jumlahperantau-pulang-kampung? page $=$ all

Wilson, M. E. (2005). Travel and the emergence of infectious diseases. Journal of Agromedicine, 9(2), 159177.

https://doi.org/10.1300/J096v09n02_ 10 